American Journal of Environmental Sciences 7 (3): 200-206, 2011

ISSN 1553-345X

(C) 2011 Science Publications

\title{
Trends Analyses for Several Factors Affected by Tropical Cyclones
}

\author{
${ }^{1} \mathrm{Md}$. Toriqul Islam, ${ }^{2} \mathrm{Md}$. Zakaria Hossain and ${ }^{1}$ Masaaki Ishida \\ ${ }^{1}$ Department of Sustainable Social Systems, \\ ${ }^{2}$ Department of Environmental Science and Technology, \\ Graduate School of Bioresources, Mie University, \\ 1577 Kurimamachiya-Cho, Tsu-City, Mie 51408507, Japan
}

\begin{abstract}
Problem statement: This study presents an analytical investigation for the trends of several factors such as number of death of peoples, damages of wealth, flood surge heights, wind speed and radius of the severe storm due to tropical cyclones in Bangladesh. Approach: The study is performed by conducting the field visits to cyclone site, collected data and information on damages and deaths of peoples during field visits, necessary data related to tropical cyclones obtained from available publications and news-study. The data since the period of the independence of Bangladesh (nearly 40 years) are analyzed. Results: The analyses showed that the 17 major cyclones have been occurred since 1970. Among these 17 major cyclones, the 5 cyclones were tragically severe that killed over 400 thousand peoples. It is observed that the coast of the Bay of Bengal is particularly vulnerable to tropical cyclones. It is revealed that Bangladesh is more vulnerable to devastating cyclones in the recent years because the frequency of the severe cyclones has increased remarkably. Conclusion/Recommendation: The return period of the major cyclones was decreased drastically in recent years and the country, especially, the Bengal Bay is predominantly helpless during the cyclone seasons.
\end{abstract}

Key words: Frequency analyses, deadliest tropical, major cyclones, return period, affected areas, cyclones occurred, warning system, fully damaged, south western, organizing simulated

\section{INTRODUCTION}

The country Bangladesh, especially the Bay of Bengal is vulnerable to cyclones causing enormous disruptions, damages and remarkable number of death of peoples. The cyclones occurred in the year of 1970 (Bhola), 1991 (Tropical), 1999 (Orissa), 2007 (Sidr) and 2009 (Aila) are some of the examples. The 1970 Bhola cyclone was a devastating one that struck on November 12, 1970 (Anthes 1982; Barry et al., 1993). It was the deadliest tropical cyclone ever recorded and one of the deadliest natural disasters in modern times. More than 250 thousand people lost their lives in the storm, particularly as a result of the storm surge that flooded much of the low-lying islands of the Ganges Delta. This cyclone was the 6th cyclonic storm of the 1970 north Indian Ocean cyclone season and was also the most powerful, reaching a strength equivalent to a category 3 hurricane. This cyclone formed over the central Bay of Bengal on November 8, traveled north and intensified. It reached its peak with winds of 185 $\mathrm{km} / \mathrm{h}(115 \mathrm{mph})$ on November 12 and made landfall on the coast. The storm surge devastated many of the offshore islands, wiping out villages and destroying crops throughout the region. The city of sub-district (Tazumuddin), was the most severely affected, with over $45 \%$ of the population of 167 thousand killed by the storm (Paul and Rahman, 2006; Gornall et al., 2010).

Another cyclone which struck Bangladesh on the night of 29-30, April, 1991 was particularly severe causing widespread damage, killing nearly130 thousand people (Merry et al., 2009; Mushtaque et al., 2007). There has been massive damage to life line systems as well as private properties. Total loss has been estimated at US\$2.07 billion dollars for all sectors. Cyclone on 18th October, 1999 hit on the eastern cost of India along the Bay of Bengal affecting the coastal districts of Ganjam, Puri, Jagatsinghpur, Khurda, Gajapati and Balasore. Subsequently, the State was hit by a Super Cyclone on 29th October, 1999 with winds of more than $250 \mathrm{~km} \mathrm{~h}^{-1}$, tidal waves rising $7 \mathrm{~m}$ high and torrential rains. The Super Cyclone and its aftermath caused severe damage in the districts of Jagatsinghpur, Balsore, Cuttack, Puri, Nayagarh, Jajpur Kendrapada, Bhadrak and Khurda and moderate damage in the

Corresponding Author: Md. Zakaria Hossain, Graduate School of Bioresources, Mie University, Japan Fax: +81592319591 
districts of Mayurbhanj, Dhenkanal and Keonjhar. In 2007, Bangladesh suffered a natural disaster like the cyclone Sidr of November 15, an unusually powerful storm that triggered giant waves up to $8 \mathrm{~m}$ high and killed more than 10 thousand people in the south western coastal belt of Bangladesh covering the districts of Bagerhat, Barisal, Patuakhali, Pirozepur, Khulna and Satkhira. Even 5 days after the calamity, in village after village along the battered roads of the coastal districts, the survivors of the storm, their cheeks hollow and eyes sunken from hunger wait in vain for relief to come. Natural disasters cannot be stopped, however, the deaths and damages can be minimized depending on the preparedness. If the country has organized plan, rehabilitation can also be effective. Unfortunately, Bangladesh has not yet sufficient plan. Accompanied by $260 \mathrm{~km} \mathrm{~h}^{-1}$ ravaging winds and sea surge as high as $8 \mathrm{~m}$ that swept about $20 \mathrm{~km}$ inland, a grade 5 hurricane, the highest level possible, devastated 23 districts in the south western part of Bangladesh at midnight on November 15, 2007 (European Community, 1998). The country is yet to fully repair many of the damages done to her infrastructure due to devastating flood occurred in the same year just three months ago (Hossain and Sakai, 2008; Hossain et al., 2008). Agricultural infrastructures such as farm structures, irrigation structures, dairy, poultry, fisheries, shelter, sanitation, drinking water, electricity supplies, transportation services including both land and water transports are in great danger in the region of Bay of Bengal where natural disasters occur frequently. Some destruction due to devastating Sidr in term of damages of houses, flooding and fallout and uprooted of trees is shown in Fig. 1. In view of the above objectives, a comparative study of the major cyclones those struck Bangladesh in the last four decades especially just before and after the independence of Bangladesh. Along with the trend analyzes, this study also reports some countermeasures of tropical cyclones of Bangladesh taken by the government of the country. Data collected during the field visits to cyclone site, information on damages and deaths of peoples published in technical literature and news papers are analyzed and demonstrated. Along with the damages of previous cyclones, the disruptions, damages and death of peoples occurred in the year 2007 and 2010 are illustrated in various charts for better comparison.

The return period of destructive cyclones, frequency, warning system of the weather broadcasting center and the countermeasures taken by the government of the country are depicted in this study. Damages of agricultural and engineering infrastructures such as rural roads, embankments, water sanitation, shelters and food security are also discussed.
Physical facts: The path of the five severe cyclones along with the physical facts of Bangladesh is shown in Fig. 2. It should be noted that Bangladesh extends between 21 and $27^{\circ}$ North latitude and $88^{\circ}$ and $92.5^{\circ}$ East longitude. The Bay of Bengal is in the south side of the country. The total area is 144 thousand sq $\mathrm{km}$ and size of population is around 16 million (2010). Per capita income is around US\$ 650, one of the lowest in the world. The coastal land of Bangladesh $(710 \mathrm{~km}$ long) is of recent origin formed out of the process of sedimentation. Most parts of the area are, therefore, low lying which can be subject to inundation even under ordinary circumstances of tides. A tidal surge accompanied by a cyclone storm makes the situation alarming which is further exacerbated by the triangular shape of the Bay of Bengal (Fig. 2).

The wide shallow continental shelf is conducive to amplification of surges causing wide spread flooding. The country has been subjected to frequent natural disasters in many forms, particularly cyclonic storms and tidal surges. From 1970 to 2011, five major cyclone storms and tidal surges have been reported. These indicate that Bangladesh is prone to frequent destructive tropical cyclones associated with tidal surge. The low-lying coastal areas are particularly vulnerable, thus placing these population, infrastructure, agriculture, livestock and economic development in a high-risk situation. During the 1991 cyclone, the cyclonic storm was detected as a low pressure area over the Southeast Bay and adjoining Andaman Sea on 23 April. Finally, the cyclone of hurricane intensity crossed the Chittagong coast a little north of Chittagong at 2 am of 30 April, 1991 that killed some 143 thousan people in Bangladesh. The aspects of the detection of the cyclone, its monitoring and prediction and weakness of warning and special weather bulletins have been reflected upon. Most of the worst affected sub-districts are either off-shore islands or coastal areas. The less affected areas are mostly located inside and further from the coast. The 2007 cyclone Sidr smashed into the country's southern coastline late on Thursday midnight of November 15 with $250 \mathrm{~km} \mathrm{~h}^{-1}\left(155 \mathrm{~m} \mathrm{~h}^{-1}\right)$ winds that whipped up a five meter tidal surge and swept about $20 \mathrm{~km}$ inland, a grade 5 hurricanes, the highest level possible, devastated 23 districts in the south western part of Bangladesh. Gigantic walls of water smashed into the coastline, washing away everything in their path. The backwash dragged hundreds of people into the sea, bodies were towards the shoreline -- twisted, bloated and broken -- washing up from the overflowing creeks and ponds around the villages. Death and its nauseating stench were everywhere. 


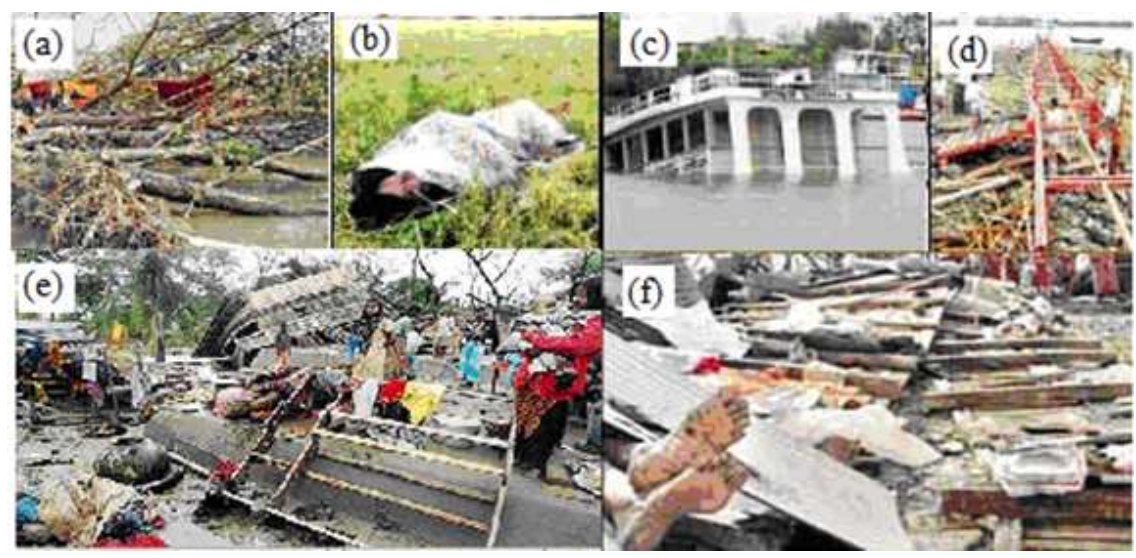

Fig. 1: Severities and damages of Sidr, 2007 (Daily Inquilab), (a. uprooted, b. death, c. flooded, d. fallout, e. ship destruction, f. house damaged)

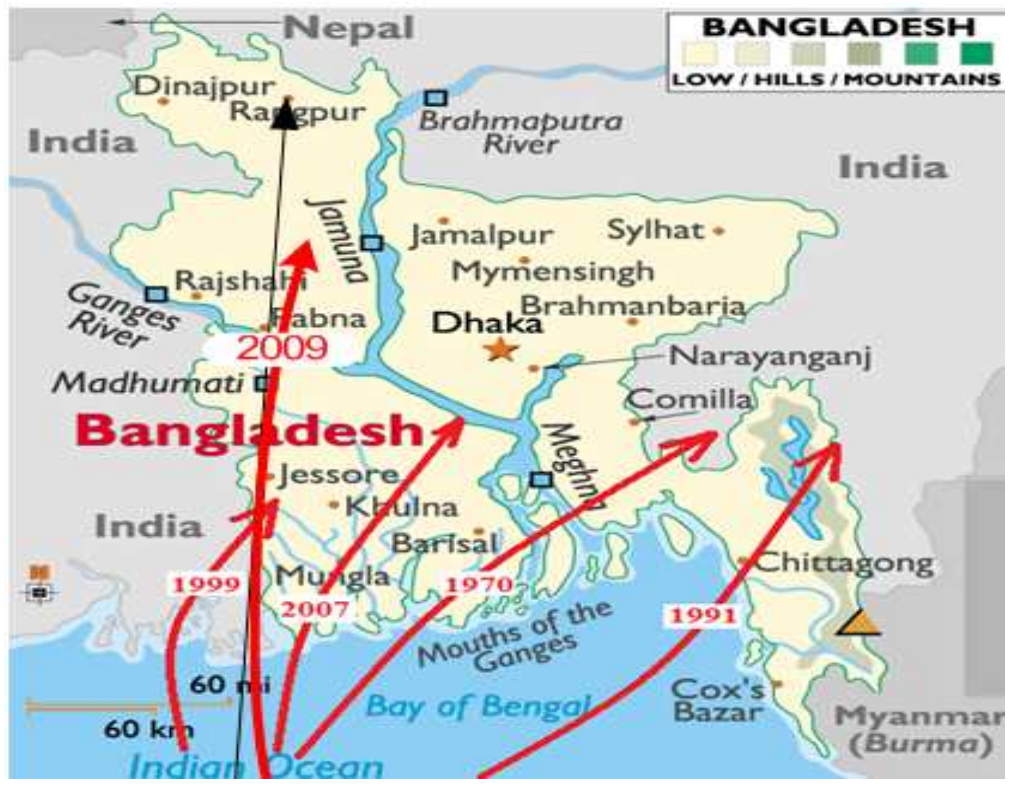

Fig. 2: Physical facts and path of severe tropical cyclones in Bangladesh

Just within the two years of divested Sidr cyclone, another strong cyclone called as Aila has falled down on 26th May 2009 at the coast of Bangladesh with wind speed of $120 \mathrm{~km} \mathrm{~h}^{-1}$ causing fatalities of 325 peoples and 8 thousand peoples missing. It was estimated that Aila causing damages of the properties equivalent to nearly 254.5 million US dollar.

\section{RESULTS}

Wind speed and storm surge: In order to understand the severity of storm of the tropical cyclones in Bangladesh, a comparative study of the maximum wind speed and storm surge of major cyclones those struck in Bay of Bengal during the last four decades is depicted in Fig. 3-4. The high power of the storm was mainly due to the higher wind speed which is apparent from Fig. 3 for all the cases after 1970. In 1970 that is known as Bhola cyclone, though the wind speed was not as high as of the recent cyclones that can be found in 1991, 1998, 2007 and 2009, however, the number of casualties was severe at that time. The wind speed of Bhola cyclone was nearly $227 \mathrm{~km} \mathrm{~h}^{-1}$ whereas the others were over $230 \mathrm{~km} \mathrm{~h}^{-1}$ such as 257,237 and $247 \mathrm{~km} \mathrm{~h}^{-1}$ for the cyclones occurred in the year of 1991, 1999 and 2007, respectively. 
The wind speed of Aila in 2009 was little low and recorded as $120 \mathrm{~km} \mathrm{~h}^{-1}$. The storm surge, on the other hand, was recorded as 7.8, 8.8, 8.1, 8.4 and $3.0 \mathrm{~m}$ for the cyclones occurred in the year of 1991, 1999, 2007 and 2009, respectively, as shown in Fig. 4. The radius of the major cyclones is shown in Fig. 5.

The number of death of people and the damages due to major cyclones in Bangladesh are given in Fig. 6 as the line graphs for the sake of clarification of the ferocious devastation brought to Bangladesh by the cyclones in just 37 years. Although the wind speed and tidal surge was lower for the 1970 Bhola cyclone, than the recent ones, the number of death of people was extremely higher at that time. It was estimated that more than 250 thousand people was died during the 1970 Bhola cyclone. It was saying that this was the deadliest one in the earth in its history. On the other hand, the 1991 cyclone was also other deadliest tropical cyclones on record that struck greater Chittagong with strong winds and storm surge, killing at least 140 thousand people and leaving as many as 10 million people homeless and destroying 1 millon homes. The damage of property was estimated at 1.2 billion US dollar in 1991(Constant price at 2011). The damage in 1999 and 2007 is noted as 2.6 billion and 804.1 million US dollar. A large number of boats and smaller ships ran aground. Bangladesh Navy and Air Force were also heavily hit. BNS Isha Khan Naval Base was flooded, with heavy damage to the ships. Most of the fighter planes of the Air Force were also damaged. In Fig. 6, comparison between the death of people and the damages of properties (agricultural crops and houses) are shown. The data shown in terms of money in US\$ during the past five major cyclones, It is observed that there is an increase of the damages of properties while the number of death of people is getting to decrease significantly by the year of 2000 . However, after the year of 2000, both the number of death of people and the damages of the properties are getting to decrease. It is evident that the damages of the properties are remarkably decreased after 2000. This clearly indicates the awareness and preparedness of the people in the coastal region, improvement of weather broadcasting system and countermeasures taken by the government of the country such as construction of cyclones shelters, embankments, dams etc. However, these measures could not be considered enough yet and more action need to be taken to minimize the death and damages of the peoples, their homes, cattle, agriculture, forestry and fisheries, as well as its environment, bio-diversity, Sundarbans (world largest mangrove) and wildlife. An estimated 58 thousand animals were killed by the storm with up to 50 thousand deer missing. On the island of Nizum Dwip, nearly all structures on the island were severely damaged or destroyed, leaving roughly 20 thousand people homeless throughout the country, Aila left an estimated 500 thousand people homeless. Later press reports stated that more than 6 thousand people were injured by the storm and 3.3 million were affected.

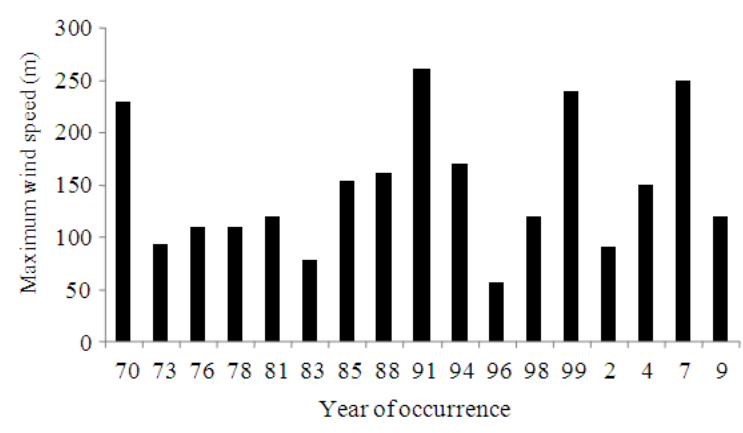

Fig. 3: Wind speed during the major cyclones in Bangladesh

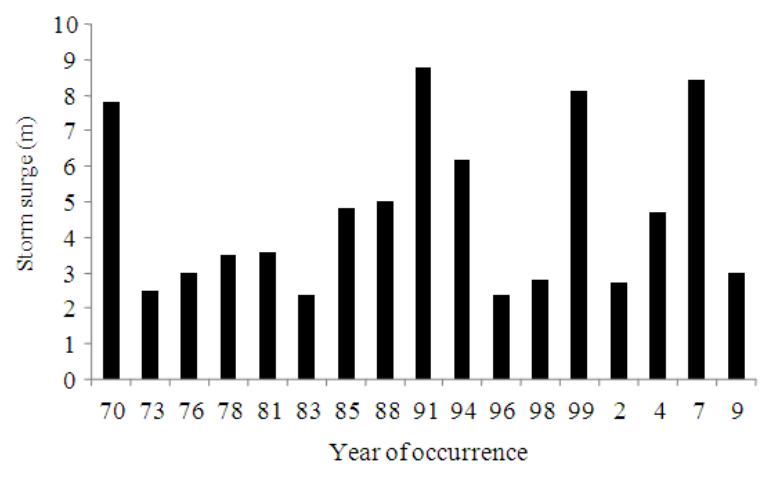

Fig. 4: Flood surge height during the major cyclones in Bangladesh

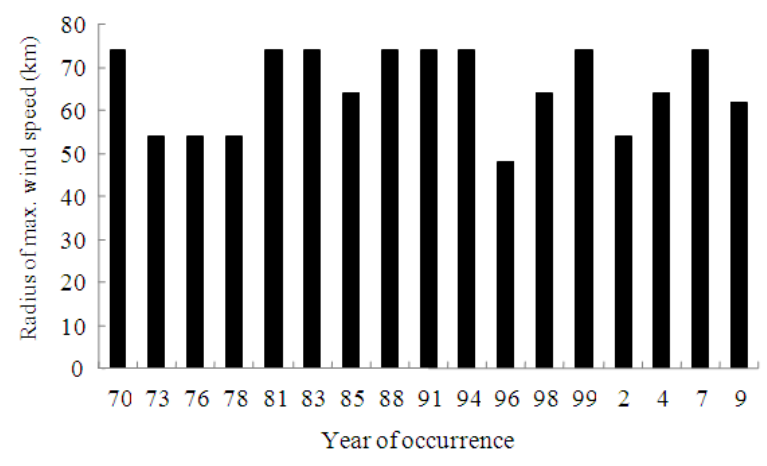

Fig. 5: Maximum radius of major cyclones 


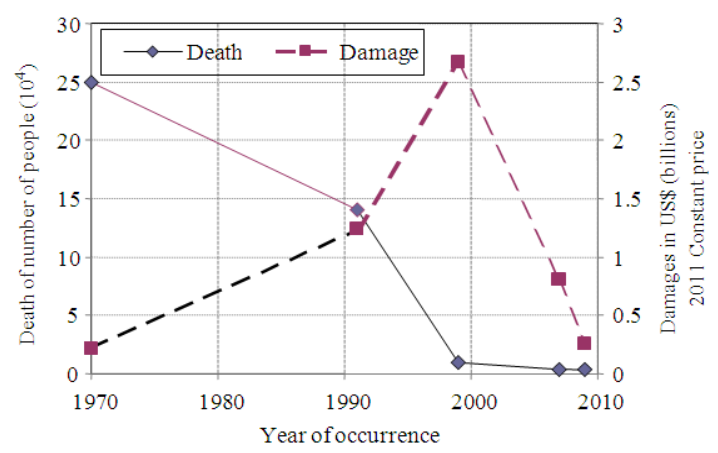

Fig. 6: Number of death of people and damages of severe cyclonic storms in Bangladesh

\section{DISCUSSION}

Victims rehabilitation: There were a lot of Sidr victims not only in the coastal region but also in the regions neighboring the path of Sidr as it passes on the capital of the country. An example of some of the Sidr victims from the union-3 in Sharonkhola in Bagerhat is shown in Fig. 7. Victims are living on a road in makeshift houses as their locality was torn up by the devastating cyclone on November 15. Rehabilitation program for Sidr-affected areas has been undertaken by the local authorities along with the government of the country and NGOs. This included economic rehabilitation, infrastructure development, disaster preparedness programs and climate adaptation programs to strengthen the region's defense against future natural disasters (Paul, 2010).

Countermeasures: The government has taken a number of countermeasures to prevent the lives of the peoples in the coastal regions especially after the Great Bhola Cyclone of 1970. An example of concrete cyclone shelters that was built in the cyclone prone area is shown in Fig. 8. The construction of cyclone shelters was accelerated after the 1991 cyclone. This process is continued till to date and further reinforced after the recent cyclones. Bangladesh now has over 2500 multipurpose cyclone shelters some of it is used as primary schools also. The recent warning system in Bangladesh is fairly effective at notifying the population of an approaching cyclone. Earlier many residents were chosen not to evacuate to the shelters, since most of them are in poor condition with minimum or no maintenance at all. But now-a-days, peoples of the country are aware and showing much more response to the weather information than earlier that saves many lives in 2007. Along with the government action, the NGOs also have devised cyclone preparedness programs, building shelters, organizing simulated cyclone evacuation exercises and educating villagers in the most exposed areas on how to flee.

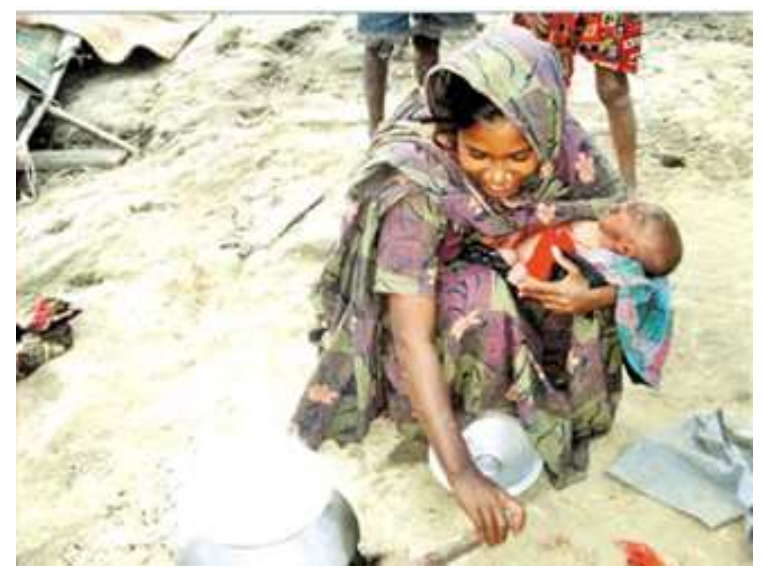

Fig. 7: Scores of Sidr victims in Bagerhat living on a road (Source: Daily Inquilab)

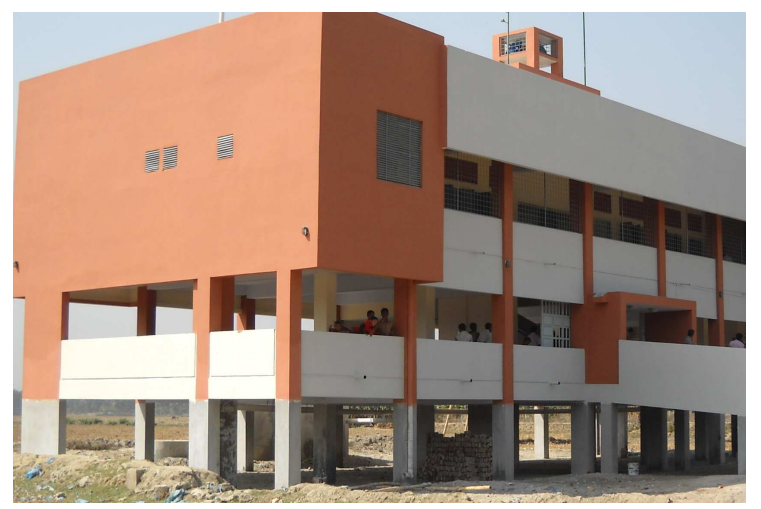

Fig. 8: Cyclone Shelter built in 2010 by the Swiss Agency for Development and Cooperation SDC (Source: Google Earth, ID: 49968016)

Efficient early warning systems and the widespread use of mobile phones meant that this time even people in remote regions were aware of the impending disaster. On-time information had reduced the extent of the destruction. Before the 1999 cyclone, weak technological strength and the lack of practical knowhow were the main obstacles to implementing the strategy in the country.

But, recently information and communication technology, especially mobile phones and internet facilities along with the improvement of weather broadcasting technology greatly adds to an effective disaster management along with global T.V. channels and web sites. This involved preparing, warning, supporting and rebuilding the society before occurrence of the Sidr. However, a slight variation of landfall timing was observed. While there was a lot to cover in terms of accurately predicting, it was not clear where 
exactly the centre of the cyclone and when it was going to make landfall and what would be its intensity and impact. The major challenge was to convert this information into a timely evacuation plan. On mid-day of Wednesday 14th November, 2007 many people were evacuated to the cyclone shelters because of the cyclone warning of Bangladesh Meteorological Department. The Storm Centre of BMD in its bulletin forecasted that Cyclone Sidr would make landfall by noon. According to the Disaster Management Bureau, when the people who took shelter saw that cyclone had still not come, they thought it would not materialize and left the cyclone shelters for their homes. Many of these people felt victim to the fury of the cyclone. BMD came under heavy criticism for having forecasted landfall ahead of time.

Agricultural and socio economic conditions: Food security: According to UN (United Nation, 2007), more than 1.6 million acres of cropland was reportedly damaged. The main crop damaged was rice that was under cultivation during this Aman season. Unlike many other regions in Bangladesh, the area affected has a single harvest during the months of November thru January. Thus the timing of the cyclone was particularly harmful, in that many of the crops were at or nearly ready for harvest. A quarter of ready-toharvest crops have been destroyed. Many households lost their food stocks as a result of severe damage to housing. Large numbers of cattle, buffalos, goats and poultry have been killed. The government of Bangladesh estimated that nearly 382,000 livestock animals were killed; the large majority of these were believed to be cattle. The UN assessment team members witnessed many animal carcasses floating in the rivers or washed up on the river banks. Livestock losses represent not only a loss of critical household assets, with an associated loss to wealth and income, but also a loss in milk production for own consumption. In coastal areas fish were a key source of food and animal protein. During the near term period fish consumption in the diet was declined, as catches were reduced due to either damage to boats and nets . and/or the unavailability of labor which was diverted to other critical activities such as housing repairs and reconstruction. Fish production from household ponds and shrimp fisheries was also declined, as many ponds and shrimp cultivation areas were badly damaged and littered with storm wreckage and debris. Many small shops selling food in worst affected areas were severely damaged due to strong winds and falling trees. Food prices were already high prior to the storm due to high international food prices and earlier flood related losses, prices were high further after cyclone. Physical access to food markets has been disrupted in some of the worst affected areas; however most of the trees blocking roads and thereby hindering the transport of food to market areas have been cleared and so food availability in the markets was not a major concern. Where housing damages were particularly bad, household kitchens and cooking areas had been badly affected, with serious implications for the ability to cook and utilize food. Although the affected population was able to salvage some possessions, many people were unable to cook due to missing utensils.

Shelter: Housing damages were the most visible and tangible damages associated with cyclone. For worst affected areas UN assessment team members witnessed numerous cases of flattened, overturned or sideways leaning household structures. Piles of damaged housing and construction materials were common within the hardest hit residential areas. The total number of houses damaged was nearly 1.2 million, approximately $30 \%$ of those were reported as fully damaged and the remaining $70 \%$ partially damaged. Approximately 697 thousand houses were damaged within only five districts. In many Upazilas more than half of thatched-roof homes, primarily inhabited by the extreme poor, were completely destroyed. A high proportion of woodframed houses with corrugated iron roofs had been destroyed or severely damaged in coastal areas. Less extensive damage was observed at locations further in land or north of the coast.

Water and sanitation: Damage to sanitation facilities and infrastructure was significant. For some of the worst affected areas, one estimate puts the percentage of slab latrines damaged or destroyed as high as $70 \%$. The affected population was vulnerable to outbreaks of diarrhea and other hygiene-related diseases. Drinking water sources in many communities had been contaminated by saline and debris. Power outages had affected water supplies in areas with piped water (Prasad et al., 2009).

Transport: There was widespread damage to transport and communications networks. Rural roads and many of the embankments protecting such roads, were extensively damaged. Most of the road damage was associated with the tidal surges in coastal areas. Large uprooted trees on roadsides also account for some of the damages, as trees were uprooted segments of tarmac or earthen roads became cracked or fragmented. Damage to transport infrastructure in coastal and inland waterways had occurred. Numerous ferries and associated landing and loading areas damaged. In more 
than a few cases, the storm surge was so strong that medium to large sized ferries were actually lifted clear out of the water and beached on neighboring land.

\section{CONCLUSION}

The study analyzes the extent and severity of tropical cyclone in Bangladesh and its countermeasures taken by the government of the country along with the NGOs'. There were five deadliest storms since 1970 in the Bay of Bengal and Sidr and Aila were the recent cyclones that had hit the region of Bangladesh in just 40 years since 1970. Particular emphasis was given to investigate the trends of several factors such as number of death of peoples, damages of wealth, flood surge heights, wind speed and radius of the severe storm due to tropical cyclones in Bangladesh. Extensive technical reports and news-paper information were taken into account. Along with the literature review, data were collected through people's interview during field visit to cyclone affected area. The data of several factors for a period of 40 years are analyzed. Results showed that the 17 major cyclones have been occurred within 40 years period since 1970 . Over 400 thousand peoples have been killed by the 5 gigantic cyclones. The return period of the major cyclones was decreased drastically in recent years and the country, especially, the Bengal Bay is predominantly helpless during the cyclone seasons.

\section{REFERENCES}

Anthes, R.A., 1982. Tropical Cyclones, their Evolution, Structure and Effects. 1st Edn., Amer Meteorological Society, ISBN-10: 0933876548, pp: 208.

Barry, P.J., C. Doggett, R.L. Anderson and K.M. Swain, 1993. How to evaluate and manage storm-damaged forest areas. Manage. Bull. R8-MB, 63: 11. http://www.fs.fed.us/r8/foresthealth/pubs/storm_da mage/contents.html

European Community, 1998. Cyclone Shelter Preparatory Study (CPSP), Stage I, Feasibility Study, Draft Final Report. DOI: 10.1111/j.16000870.2007.00251.x
Gornall, J., R. Betts, E. Burke, R. Clark and J. Camp et al., 2010. Implications of climate change for agricultural productivity in the early twenty-first century, Philo. Trans. Royal Soc. London. Series B, Biol. Sci., 365: 2973-89. DOI: 10.1098/rstb.2010.0158

Hossain, M.Z. and T. Sakai, 2008. Severity of Flood Embankments in Bangladesh and Its Remedial App. Agric. Eng. Int., CIGRE J., 37: 1-11. ISSN: 1682-1130

Hossain, M.Z., M.T. Islam, T. Sakai and M. Ishida, 2008. Impact of Tropical Cyclones on Rural Infrastructures in Bangladesh. Agric. Eng. Int. CIGR E J. Invited Overview, 2: 1-13. ISSN: 1682-1130

Merry, K., P. Bettinger and J. Hepinstall, 2009. Physical and biological responses of forests to tropical cyclones affecting the united states Atlantic ocean and gulf of Mexico coasts. Am. J. Environ. Sci. 5: 16-32. http://www.cabdirect.org/abstracts/20093014842.ht $\mathrm{ml}$;jsessionid=A3F48636A37BE2AE1A41AB9CA 53308A0

Mushtaque, A., R. Chowdhury, A.U. Bhuyia, A.Y. Choudhury and R. Sen, 2007. The Bangladesh cyclone of 1991: Why so many people died. Disasters, 17: 291-304. DOI: 10.1111/j.14677717.1993.tb00503.x

Paul, B.K., 2010. Human injuries caused by Bangladesh's cyclone Sidr: An empirical study. Nat Hazards, 54: 483-495. DOI 10.1007/s11069009-9480-2

Paul, A. and M. Rahman, 2006. Cyclone Mitigation Perspectives in the Islands of Bangladesh: A Case of Sandwip and Hatia Islands. Coastal Manage., 34: 199-215. DOI: 10.1080/08920750500531371

Prasad, S., T. Aung and A. Singh, 2009. Analysis of water properties and geostrophic currents in fiji waters before and after tropical cyclone gene. Am. J. Environ. Sci., 5: 455-460. http://www.cabdirect.org/abstracts/20093242066.ht $\mathrm{ml}$

United Nation, 2007. Cyclone Sidr United Nations Rapid Initial Assessment Report, With a Focus on 9 Worst Affected Districts. ISSN: 1174-4707 